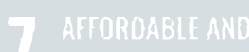 \\ RITAN ENTRGY

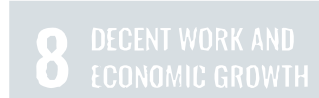 \\ BRIEFING NOTE: \\ Aligning International Investment Agreements with the Sustainable Development Goals
}
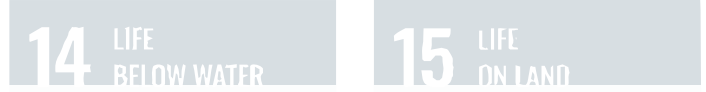

\section{November 2020}

Lise Johnson, Lisa Sachs, and Nathan Lobel
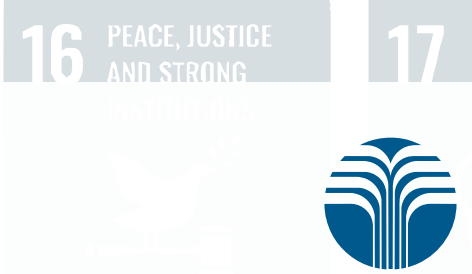

PARTNERSHIPS

$4 \square$

\section{Columbia Center}

on Sustainable Investment

A JOINT CENTER OF COLUMBIA LAW SCHOOL AND THE EARTH INSTITUTE, COLUMBIA UNIVERSITY

\section{Abstract}

\section{Table of Contents}

I. Introduction: The Need for New Thinking on International Investment Policy

II. IIAs and SDG-Advancing Investment

Catalyzing and Channeling Investment

for the SDGs

Not Subsidizing Harmful Investments

III. IIAs and SDG-Advancing Governance

Supporting Fair and Inclusive Policy-

Making Processes

Protecting Appropriate Policy Space to

Regulate Investments

IV. IIAs and SDG-Advancing International Cooperation

Combatting Races to the Bottom

Closing Transnational Governance Gaps

Anticipating, Understanding, and Addressing

Treaty Effects in State Parties

Addressing Relevant Global Commons

Challenges

V. Conclusion
Full Paper available at: http://ccsi.columbia.edu/ aligning-investment-treaties-with-sustainable-development/.
International investment agreements ("IIAs") provide enforceable protections to foreign investors based on the premise that enforceable investor protections will stimulate greater foreign investment flows, which, in turn, are assumed to promote development. However, as understandings of both the effectiveness of these agreements as well as the effects of investment and investment governance on sustainable development have evolved, it is not clear that IIAs, as currently designed, are fit for their purpose of promoting development. Worse: they may be undermining efforts to achieve the Sustainable Development Goals. Change is, therefore, essential. In this note, we summarize our proposal that IIAs should be designed and evaluated with respect to their ability to:

- Encourage and channel investments that contribute to sustainable development, and do not support harm-causing investments;

- Foster, and not constrain, responsible, SDG-advancing governance at the national level; and

- Promote international cooperation to overcome transnational and collective action challenges related to the governance of international investment. 


\section{Introduction: The Need for New Thinking on International Investment Policy}

Achieving the Sustainable Development Goals (SDGs) will require the tremendous mobilization and re-alignment of public and private investment. Indeed, the 2030 Agenda for Sustainable Development recognized the need for governments to encourage "financial flows, including foreign direct investment, to States where the need is greatest," and to "[a]dopt and implement investment promotion regimes for least developed countries." ${ }^{1}$ Similarly, it recognizes that not all investment is the same and that governments must be able to regulate it to maximize its public benefits and minimize those costs.

Indeed, foreign direct investment ("FDI") can play an important role in achieving the SDGs; FDI can be an efficient and effective way to transfer capital and technologies across borders and, when the proper policies and conditions are in place, an important means to spur environmentally sound economic growth and development through employment, infrastructure development, tax revenues, and other economic linkages and spillovers.

However, FDI does not automatically generate positive environmental, economic, and social outcomes, and can, at times, harm host countries and communities. Even when FDI does generate positive outcomes, the price paid to attract FDI (e.g., through fiscal or financial incentives, or relaxed or waived social or environmental regulations) may outweigh the benefits obtained. Laws, policies, and practices in host and home countries, and at the international level, instrumentally shape both whether FDI ultimately contributes to sustainable development and how it impacts affected stakeholders and the planet.

At the international level, the network of over 3,000 international investment agreements ("IAs") comprises a notable and potent portion of the relevant governance framework. ${ }^{2}$ These agreements provide protections and other benefits to foreign investors, usually enforceable through investor-state dispute settlement ("ISDS"). Support for IIAs is largely based on the premise that enforceable investor protections will stimulate greater foreign investment flows, which, in turn, are assumed to promote development of the treaty parties. ${ }^{3}$

However, the veracity of this premise is uncertain at best. First, states and other institutions have grown to appreciate that not all investments contribute to development and policy interventions are often needed to ensure that the benefits of investment are captured and the harms are avoided. ${ }^{4}$ Second, a growing body of research questions whether IIAs actually deliver on their stated promise to increase investment flows, never mind at what cost, and never mind whether those flows help or hinder the host or home countries' development. ${ }^{5}$ Third, new research alleges that substantive and procedural aspects of investment treaties exacerbate inequality, ${ }^{6}$ undermine the rule of law, ${ }^{7}$ and negatively impact states' willingness and ability to adopt and enforce environmental and public health measures. ${ }^{8}$

Informed by this growing body of literature on and experience with the costs and benefits of IIAs, various governmental, civil society, and academic stakeholders have begun to discuss whether IIAs, as currently designed, implemented, and enforced, are the appropriate standards for international economic governance and, if not, how they should be reformed. ${ }^{9}$

The SDGs provide a framework against which today's analysts can evaluate the features and effects of existing IIAs and consider the role such agreements could play. This paper argues that existing or re-imagined IIAs should be evaluated with respect to their ability to:

- Encourage and channel investments that contribute to sustainable development, and withhold benefits from those that do not;

- $\quad$ Foster, and not constrain, responsible, SDG-advancing governance at the national level; and

- Promote international cooperation to overcome transnational and collective action challenges related to the governance of international investment.

While we affirm the importance of FDI and international investment governance to achieve the 2030 Agenda for Sustainable Development, we argue that existing IIAs are not designed to promote SDG-enhancing foreign investment nor to facilitate strategic international cooperation, and may, in fact, undermine development by supporting harmful investments and constraining governments' abilities to prevent or address those resulting harms.

\section{IIAs and SDG-Advancing Investment}

The 2030 Agenda for Sustainable Development recognizes the need to mobilize private investment to address key financing gaps in achieving the SDGs. Specifically, the Financing for Development Action Agenda identifies a need for increased investment in infrastructure, low carbon and climate resilient development, innovation and clean technologies, and sustainable agriculture, among other sectors. Yet, at present, FDI is not being directed into the locations, sectors, or activities needed to maximize impact. Moreover, FDI is continuing in projects and activities that undermine the SDGs, including, but not limited to, new fossil fuel exploration and production. The key questions this raises are: How can international agreements help to catalyze, attract, and channel SDG-advancing investments? Should IIAs withhold benefits from investments that do not advance, and potentially undermine, sustainable development? And how can and should IIAs identify whether and to what extent investments are or are not SDG-advancing? 


\section{Catalyzing and Channeling Investment for the SDGs}

A number of barriers may affect FDI inflows, including specific host country restrictions on foreign investment in particular places or sectors; legal, economic, and political environments that cause uncertainty and threaten project profitability; information asymmetries, linguistic differences, or geographical distance that make it hard to identify and pursue FDI opportunities; and home state measures, like sanctions or tax treatments that encourage repatriation over reinvestment of foreign earnings. ${ }^{10}$

States seeking to attract investment can, and do, work to address some of the policy-related barriers both unilaterally and in cooperation with other states. For instance, states address these barriers through liberalization of certain sectors, reducing performance requirements, strengthening certain property rights protections, improving the quality and speed of their administrative and judicial systems, investing in soft and hard infrastructure, and/or offering investment incentives. ${ }^{11}$ Bilaterally and multilaterally, states may also pursue tools and agreements related to investor protection, risk mitigation, and economic and political cooperation to attract and channel FDI. International instruments can also signal countries' commitments to offer certain standards of treatment or abide by certain norms; and they can include a range of mechanisms, including stateto-state peer review, informal consultations, and legalized dispute settlement, to ensure that signals align with practice and to monitor and strengthen adherence to commitments. Each of these options varies in terms of its overall effectiveness as well as its costs and benefits to investors, governments, and other stakeholders, with those costs and benefits often depending a great deal on specific context.

International Investment Agreements (IIAs) have largely focused on achieving their promotion function by locking in, at the international level, state promises to protect foreign investors from harms or losses suffered as a result of state conduct and have often coupled those protections with investor-state dispute settlement (ISDS) mechanisms that allow foreign investors to directly claim and seek remedy for breach. ${ }^{12}$ Proponents of IIAs have contended that these investment protections can catalyze international investment flows. ${ }^{13}$ But, although investment treaties might indeed affect how a company structures its investment in a host state (e.g., encouraging investors to route their investments through an intermediary state that has a strong investment treaty with the host state), ${ }_{14}^{14}$ there is no clear or consistent evidence that the thousands of existing treaties have had any significant effect on investors' decisions regarding whether and how much to invest in particular host destinations or, therefore, on catalyzing international investment and its anticipated benefits. ${ }^{15}$

However, IIAs could employ different strategies. Rather than imposing obligations on host governments regarding treatment of investments, investment treaties could address investment governance more holistically, help to identify and overcome specific barriers to investment, and include mechanisms and commitments on the part of the home state to actively promote increased cross-border investment flows, particularly in sectors and activities consistent with the states' development objectives.

Indeed, some treaties are already starting to do this. ${ }^{16}$ The Japan-Mexico Economic Partnership Agreement, for instance, explicitly includes state commitments to promote cross-border investment in activities designed to advance sustainable development and combat climate change through capacity and institutional building and informational exchange, including for the "identification of investment opportunities and the promotion and development of business alliances in the field of environment." ${ }^{17}$ The Cotonou Agreement, concluded between the EU and the members of the African, Caribbean, and Pacific ("ACP") Group of States in 2000, and subsequently amended, provides for inter-state cooperation and European Union ("EU") assistance in a range of activities that aim to increase cross-border investment flows, including capacity building for investment promotion agencies, dissemination of information regarding business opportunities in ACP states, provision of risk capital and investment guarantees, and assistance in developing relevant technical, managerial, and professional expertise. ${ }^{18}$

Brazil's Cooperation and Facilitation Investment Agreements, ${ }^{19}$ seek to advance investment promotion objectives by, for instance, establishing ombudsmen or "Focal Points" responsible for providing support to investors from the other contracting party. ${ }^{20}$ The ombudsmen, or Focal Point's, duties include providing "timely and useful information on regulatory issues on general investment or on special projects," fielding complaints from investors, and preventing potential conflicts. ${ }^{21}$

The examples of investment-related treaty provisions referred to above are arguably modest in terms of their focus on and commitments to advancing investment flows for sustainable development; nevertheless, they begin to highlight possibilities for investment treaties, if re-oriented, to more actively mobilize and shape investment for sustainable development. One could imagine more robust provisions included in IIAs such as commitments to increase investment into the less developed country partner or into particular sectors or activities as well as mechanisms to routinely evaluate among the treaty partners whether the provisions of the treaty are meeting their intentions to promote SDG-aligned investment.

\section{Not Subsidizing Harmful Investments}

In addition to more proactively promoting investments that contribute to the SDGs, so too should IIAs discourage-or at least not offer additional protections or support to-investments 
with clearly negative effects. Such investments may include, for example, investments in fossil fuel extraction and related infrastructure, investments that result from or perpetuate corrupt dealings, or investments violating international labor standards.

Both the substantive benefits and protections as well as the procedural privileges offered in investment treaties, as they have been negotiated, interpreted, and applied to date, are additional to and go further than protections offered by analogous areas of domestic and international law. ${ }^{22}$ These benefits act as regulatory incentives that, even if not effective at attracting investment, effectively subsidize foreign investments. Framed in this manner, it is uncontroversial to suggest that governments should evaluate which types of investments, investors and activities are deserving of such subsidies and ensure that the protections and benefits afforded under IIAs do not support investments that may undermine the SDGs. ${ }^{23}$

Governments, for instance, could ensure that treaty benefits do not cover:

- Investments for trade in or production of goods or services illegal in the host state, ${ }^{24}$ or investments that would significantly and irreversibly harm natural ecosystems, require resettlement of large numbers of people, ${ }^{25}$ or otherwise impact critical ecological zones; ${ }^{26}$

- Foreign investments made solely for the purpose of avoiding taxes otherwise due to the home country, such as "inversions," in which companies move overseas to reduce their tax burden; ${ }^{27}$ or

- Investment in exploration for and extraction of new fossil fuel reserves, projects that result in major deforestation harmful to biodiversity, and production and trade of harmful products for consumption in third countries, among others.

Governments risk reputational and potentially legal consequences for affirmatively supporting outward investments that harm home ${ }^{28}$ and host countries and communities, ${ }^{29}$ third countries, and the global commons. Home governments are increasingly assessing and addressing conduct and impacts of the firms they support overseas ${ }^{30}$; Canada, for instance, has indicated that it may withdraw or deny trade advocacy support and/ or financial assistance to companies that do not adhere to the government's environmental and social policies in their overseas activities ${ }^{31}$ and that do not comply in good faith with dispute resolution mechanisms instituted to ensure the companies adhere to standards of responsible business conduct. ${ }^{32}$ Government-sponsored political risk and export credit insurance schemes also often incorporate relatively robust ex ante screens and ex post exclusions designed to help ensure that beneficiaries do not have deleterious social, environmental, and human rights impacts in host countries ${ }^{33}$ and that projects contribute to development, through job creation, training, private sector development, and technology and knowledge transfer. ${ }^{34}$
Governments wanting to ensure that their IIAs do not subsidize or support harm-causing activities could exclude certain investments or types of investments from coverage, or from certain treaty protections or benefits. Exclusions could be categorical, based on the type of investment or investor activity, or could be based on subjective assessments of investments' alignment with the SDGs. In addition to categorical exclusions, IIAs could also require that investments, in order to be covered, must be "responsible"35, "comply with the law of the host state" 36 or the home state ${ }^{37}$ during the duration of the investment, and make a contribution to the host state's economic development. While treaties could usefully exclude harmful investors or investments from treaty coverage, treaties should at very least limit access to ISDS and associated remedies for such investors or investments, even if the protections broadly remain.

\section{IIAs and SDG-Advancing Governance}

The positive or negative impacts of an investment project are not necessarily inherent to the project, allowing for the specific inclusions or exclusions described above, but often depend to a significant degree on the specific corporate policies and practices as informed, regulated, and enforced by relevant domestic and international governance frameworks. Given the importance of governance to investment outcomes, and the intrinsic importance of justice, rule of law, and strong institutions (as reflected in SDG 16), it is crucial to consider how IIAs affect these instrumental and normative aspects of governance. How do IIAs affect the way in which governments govern investments and try to influence their economic, social, and environmental outcomes?

\section{Supporting Fair and Inclusive Policy-Making Processes}

IIAs are often cited as tools that can be used to improve the rule of law and good governance by holding governments accountable for abuses of authority. ${ }^{38}$ Yet, while in theory this might be plausible, ${ }^{39}$ evidence of any improvement remains lacking. ${ }^{40}$ Indeed, studies have found that BITs and ISDS claims may have negative effects on the rule of law. ${ }^{41}$

First, allowing foreign investors to circumvent domestic legal systems to pursue claims in international arbitration can undermine the role and perceived authority and legitimacy of domestic institutions. Investment treaties could, but currently do not, contain provisions or mechanisms to build capacity of and trust in courts or administrative bodies to better ensure that investors (both foreign and domestic) have access to fair, effective, and efficient legal systems. The approach taken in IIAs contrasts with the approach taken in international human rights law. Under IIAs, investors can use ISDS to bypass domestic courts. In human rights law, individuals (and sometimes corporate entities) can also bring claims against governments, but its supra-national mechanisms are designed to be instruments for advancing 
domestic reforms, and recognize the crucial role of domestic systems as the main targets for and implementers of those reforms. ${ }^{42}$

Second, ISDS undermines principles of equality before the law where covered investors have, through substantive protections enforceable through ISDS, (1) greater power relative to both the host state government and other private parties; and (2) greater substantive standards of protection, strengthening the legal force of their economic rights and "expectations" to the potential detriment of competing rights and interests. ${ }^{43}$ These inequalities provided under the law can entrench and exacerbate inequalities in economic, social, and political terms. The Fair and Equitable Treatment ("FET") standard, for instance, which has been used to enforce protections of investors' legitimate expectations and favors stability over change, stands to significantly constrain states' abilities to adapt policy frameworks to fight inequality. Investors have also used ISDS to challenge the attempts of traditionally marginalized voices to assert legal and political power. ${ }^{44}$ When there is a contest among levels or branches of government (local vs. central, mining ministry vs. environmental ministry, or executive vs. judiciary) about whether to approve and how to govern a project, IIA protections and privileges can potentially influence the outcomes in pro-investor directions. Moreover, individuals and communities affected by the relevant investment have no legal right to participate in or shape ISDS proceedings (or, indeed, even follow the developments of certain proceedings), leading arbitrators to base their decisions on a narrow and incomplete view of the law and facts and to produce decisions that shape the law so as to be disproportionately attentive to only investors' economic interests. ${ }^{45}$

Third, the issues outlined above are compounded by investment treaties' express and implied notice-and-comment rules, requiring governments to publish advance notice of proposed actions and to respond to questions and comments received from foreign investors and other constituents. ${ }^{46}$ These requirements have been interpreted as forming part of the FET obligation. ${ }^{47}$ While these obligations may be expected to advance the rule of law and improve government transparency, accountability, and decision-making, they risk providing undue space for non-agency actors, including foreign investors, to determine the shape and fate of proposed regulatory actions through submission of public comments, private communications, and/or other lobbying activities. An investor can raise the threat of investor-state arbitration (and the often high legal fees, expenses, liability, and reputational risks associated with it) in challenges to proposed agency actions and processes of rule-formulation, potentially influencing the outcomes of rule-making processes in ways that administrative notice-and-comment mechanisms do not. ${ }^{48}$

Public engagement on policy making can ensure a range of perspectives are heard and considered. However, with unequal resources, access, and interests and unclear rules regarding who can provide input, as well as when and how to provide that input, participatory processes can be captured or heavily influenced by certain more powerful economic interests. ${ }^{49}$ Requiring states to listen to investors' concerns, without ensuring that other stakeholders are similarly able to participate and entitled to be heard, risks exacerbating and entrenching undue corporate influence over the law. To the extent that cooperation with and input from non-governmental stakeholders is considered useful for promoting open governance, careful consideration is advised as to the right instrument or modalities to support such cooperation and how open, participatory processes can best avoid agency capture by special interests.

IIAs could avoid these issues and be designed to make positive contributions to SDG 16 . They could, for instance, integrate mechanisms to identify and address challenges faced both by investors and, crucially, by other stakeholders relating to governance of investments..$^{50}$ Treaty parties could also commit to improving the capability of governments to manage robust multi-stakeholder impact assessment processes, which can be crucial for ensuring the long-term sustainability and even basic financial viability of major investment projects. ${ }^{51}$ To the extent that investor concerns relate to unduly slow administrative or judicial proceedings, parties could cooperate to identify bottlenecks and provide resources to ensure that investors - and all other stakeholders - have access to fair, inclusive, effective, and efficient legal systems for resolving investment-related disputes, rather than supporting foreign investors to bypass domestic institutions and processes..$^{52}$

\section{Protecting Appropriate Policy Space to Regulate In- vestments}

In addition to these institutional concerns about voice, access, representation, and power in policy-making processes, IIAs' substantive and procedural investment protections hinder governments' willingness and abilities to implement and enforce policies to ensure that covered investments generate benefits, not harms, in the state parties. As explained above, whether FDI contributes to sustainable development depends on the ability of governments to adopt and enforce public interest regulations. For that reason, it is essential that states evaluate the effects of IIAs on their ability to regulate in the public interest.

Governments need policy space to be able to enact, implement, revise, and refine their policies, laws, and regulations in order to achieve sustainable development objectives. While international law, to some degree, inherently constrains domestic policy space, ${ }^{53}$ it is important to consider carefully when, why, and how international law should do so. For instance, international economic law can help restrain individual countries' beggar-thy-neighbor impulses and prisoners' dilemmas and enable governments to withstand pressure from powerful do- 
mestic special interest groups to impose protectionist measures that would benefit those special interests at the expense of the broader public.

However, empowering international economic law to interfere in sensitive, complex, and context-specific decisions made at the domestic level regarding public interests and government duties raises important concerns, including whether economic interests and concepts like "efficiency" would be prioritized at the expense of other interests and values not so readily monetized.

This background helps illustrate why IIAs generate unease. While IIAs in theory discipline protectionist conduct, investors are not bringing cases that allege discrimination on the basis of their foreign nationality. ${ }^{54}$ Rather, investors are using IIAs to impose obligations that are much more expansive in reach and open-ended in content than anti-protectionist rules, allowing for international scrutiny of domestic law, policy, action, and inaction, irrespective of the purpose of the challenged conduct. Governments can be, and have been, held liable even for good faith conduct intended to address and improve social, environmental, and economic conditions when the government's conduct intentionally or unintentionally interferes with the rights or expectations of covered foreign investors. The public interest aim or intent of the measure is not a bar to claims or a defense to liability. ${ }^{55}$

Because of the relatively vague nature of many investment treaty obligations, at least some of the concern about the impact of investment treaties is not based on the fact that they will result in claims and/or liability for states, but that there is a risk that they will; and that risk may cause governments to abandon or weaken otherwise legitimate public interest measures, particularly, but not only, in developing countries.

In order to ensure that IIAs do not frustrate states' efforts to develop and implement laws and policies in the public interest, it is important to carefully shape their substantive obligations accordingly and ensure that the treaty's dispute settlement provisions are consistent with accepted rule of law principles of transparency, certainty, and accountability.

\section{IIAs and SDG-Advancing International Coop- eration}

In addition to their role in attracting and channeling sustainable development-driving investments and promoting good governance domestically, IIAs could help to address challenges of investment governance that may be exacerbated by global corporate actors and their activities and by collective action problems.

\section{Combatting Races to the Bottom}

Through their liberalization and free-transfer provisions, IIAs make it easier for companies not only to expand but also to move their existing investments across borders. But, the agreements miss a crucial opportunity to combat the costly and often wasteful beggar-thy-neighbor incentive schemes that may result which can erode the benefits FDI otherwise might offer. A limited number of IIAs include provisions restricting certain types of regulatory incentives in order to prevent governments from creating races to the bottom by waiving or derogating from existing labor or environmental standards to attract investment. However, these provisions are rarely, if ever, enforced. Treaty parties could extend non-derogation provisions to other areas like corruption, public health, and human rights; follow the small number of recent IIAs that commit treaty partners to advance labor standards, human rights, and environmental protection in line with specified international standards; or require companies to meet certain production process standards in order to qualify for duty-free treatment.

\section{Closing Transnational Governance Gaps}

Although complex global corporate legal structures can drive up returns to shareholders and strengthen MNEs' competitive positions, they often do so at the expense of others, eroding tax bases, externalizing harms without compensating for losses caused, and unfairly tilting the playing field. Rules on corporate form and jurisdictional boundaries significantly limit the ability of governments and the public to access information about a given company, subject the company to investigation, hold the company liable, and/or collect any damages awarded.

Governments have unilaterally and collectively taken some steps to address these issues. Courts in a few domestic jurisdictions, for instance, have been somewhat softening the arguably artificial lines between corporate affiliates, limiting the ability of parent companies to avoid liability for harms caused by their subsidiaries. ${ }^{56}$ At the multilateral level, governments have been committing to increase cross-border information-sharing and collaboration on taxation of MNEs and have been working together to help understand competition effects of cross-border mergers and acquisitions, enforce their anti-trust laws, and prevent abusive market practices. ${ }^{57}$

But much remains to be done. IIAs aiming to increase MNE activities should play a role, helping to anticipate and monitor the governance gaps that MNEs fall into, or purposefully exploit, and supporting collaboration to close those gaps ${ }^{58}$ or remedy their effects. ${ }^{59}$ Relevant activities can include technical and financial support, ${ }^{60}$ agreements to cooperate on rule-making, monitoring and enforcement relating to international corporate activities, and efforts to establish funds and mechanisms to ensure access to the appropriate remedies. ${ }^{61}$ 


\section{Anticipating, Understanding, and Addressing Treaty Effects in State Parties}

Given the intention for these treaties to effect changes in investment flows and practices, states should assess the projected environmental, social, economic, and human rights impacts of investment agreements and the FDI they support and evaluate the factors that make those impacts more or less likely to occur. A robust ex ante impact assessment and effective implementation plan could map relevant environmental, health, and safety standards in the treaty partners and include relevant mechanisms and institutions for ongoing monitoring, evaluation, and action. Implementation plans could include commitments, for instance, to support treaty partners in the development and enforcement of relevant standards, including through capacity-building; to support investors, including small and medium sized enterprises, to adopt best practices in their foreign investments; to share information regarding corporate violators; to develop complaint mechanisms where employees and citizens could report violations against firms irrespective of ownership; and to monitor changes in the industry and its performance on environmental, health, and safety issues.

Some guidance and precedent exist. The SDGs provide a useful set of issues, targets, and indicators to incorporate into more robust assessments and action plans. Some governments have domestic requirements for ex ante reviews of treaties' impacts on sustainable development outcomes; and some governments also have internal processes for ex post assessment of the agreements' effects. Similarly, some treaties have mechanisms for ongoing review and implementation of their social and environmental provisions.

These domestic and treaty-based processes and mechanisms have been criticized, however. Ex ante assessments have been seen as tools for promoting negotiations and conclusions of treaties, rather than critically reviewing the potential agreements and their potential content. ${ }^{62}$ Additionally, ex post assessments have found that, in practice, provisions and institutions aimed at promoting sustainable development, and avoiding harms, have not been effectively implemented. ${ }^{63}$ Yet overall, these findings help illuminate the myriad ways in which treaties can, and do, affect environmental, social, and economic outcomes and offer lessons about what can, and should, be done in the future to improve them.

\section{Addressing Relevant Global Commons Challenges}

IIAs could also be mobilized to tackle global commons challenges, in which individual states have incentives to consume rivalrous and non-excludable common goods unsustainably. International cooperation, including cooperation relating to economic policy, is necessary in these arenas to promote more sustainable production and consumption to the benefit of all countries.

Climate change is likely the most pressing and prototypical, though surely not the only, commons problem faced today. Apart from ensuring that IIA disciplines do not unduly constrain climate policies, IIAs could impose affirmative obligations to: cooperate on identifying opportunities for investment in clean technologies; provide, on a special and differential treatment basis, support for qualifying projects; reinforce or integrate commitments under climate change agreements; and mandate corporate disclosures of GHGs, including GHGs from outward FDI. Similarly, rather than including provisions that constrain government policies regarding technology transfer, IIAs could instead include language to support technology transfer, including the commitments made in the Agreement on Trade Related Aspects of Intellectual Property Rights.

\section{Conclusion}

Revisiting IIA design in light of the SDGs requires a thorough evaluation and retooling of investment governance, with countries conducting robust assessments of the domestic and international objectives and impacts of investment treaties, and taking relevant steps to bring treaties more in line with $21^{\text {st }}$ Century goals. This is ever more important in light of the real need for international cooperation and coordination to address a number of challenges in our increasingly globalized world, especially considering the potential for international investment governance to play a role in addressing them.

Aligning existing treaties with the SDGs raises different opportunities and challenges than designing future treaties. For new treaties, countries have the freedom to craft new provisions, exclude more traditional clauses, and narrow or exclude ISDS. Bringing old treaties in line with current priorities, in contrast, can require termination, renegotiation, and/or interpretive clarification through exchange of diplomatic notes or other channels. Although addressing both existing and future treaties increases the complexity of a government's task, policy coherence and effectiveness require a backward look at the large stock of treaties already in force and a forward look at the agreements that may be concluded in the future. 


\section{Endnotes}

G.A. Res. 70/1, Transforming Our World: The 2030 Agenda for Sustainable Development, (25 September 2015) (hereinafter the "2030 Agenda for Sustainable Development"), Goal 10.b, Goal 17.5.

By the close of 2018, 3,340 IIAs had been ratified, 2,671 of which were in force. United Nations Conference on Trade and Development, International Investment Agreements Navigator, (Investment Policy Hub) https://investmentpolicyhub.unctad. org/lIA (accessed 27 December 2018). A growing minority of these agreements also includes provisions requiring investment liberalization.

The Effect of Treaties on Foreign Direct Investment (Karl Sauvant \& Lisa Sachs eds., 2009); Joachim Pohl, Societal Benefits and Costs of International Investment Agreements (OECD Working Papers on International Investment No. 2018/1, 2018). The Effect of Treaties on Foreign Direct Investment, supra note iii; Emma Aisbett, Bilateral Investment Treaties and Foreign Direct Investment: Correlation versus Causation (CUDARE Working Papers No. 1032, 2007); Lise Johnson et al., Costs and Benefits of Investment Treaties: Practical Considerations for States (CCSI 2018); Pohl, supra note iii; Jonathan Bonnitcha, Assessing the Impacts of Investment Treaties: Overview of the Evidence (International Institute for Sustainable Development Report September, 2017) https://www.iisd.org/sites/default/files/publications/assessing-impacts-investment-treaties.pdf.

Lisa Sachs \& Lise Johnson, Investment Treaties, Investor-State Dispute Settlement and Inequality: How International Rules and Institutions Can Exacerbate Domestic Disparities (Initiative for Policy Dialogue Working Paper \#306, 2018) http://ccsi.columbia. edu/files/2017/11/ISDS-and-Intra-national-inequality.pdf.

See Mavluda Sattorova, The Impact of Investment Treaty Law on Host Sates: Enabling Good Governance (2018); Tom Ginsburg, International Substitutes for Domestic Institutions: Bilateral Investment Treaties and Governance, 25 Int'l Rev. L. \& Econ. 107 (2005).

Kyla Tienhaara, Regulatory Chill in a Warming World: The Threat to Climate Policy Posed by Investor-State Dispute Settlement, 7 TEL 729 (2018); Julia Brown, International Investment Agreements: Regulatory Chill in the Face of Litigious Heat? 3(1) West. J. Legal Stud. (2013); Gus van Harten \& Dayna Nadine Scott, Investment Treaties and Internal Vetting of Regulatory Proposals: A Case Study from Canada, 7 J. Int'l Disp. Settlement 92 (2016).

The United Nations Commission on International Trade Law (UNCITRAL), for instance, has tasked one of its working groups with a mandate to catalogue concerns with investor-state dispute settlement, and discuss the desirability of reforms. Information about the working group's meetings is available at http://www.uncitral.org/uncitral/en/commission/working groups/3Investor State.html. The Commission's decision issuing the mandate is available at https://documents-dds-ny. un.org/doc/UNDOC/GEN/V17/058/89/PDF/N1705889.pdf?OpenElement. See also, e.g., United Nations Conference on Trade and Development (UNCTAD), World Investment Report 2015: Reforming International Investment Governance, 119-174 (2015); Columbia Center on Sustainable Investment, 10 th Annual Columbia International Investment Conference: Investment Treaty Reform: Reshaping Economic Governance in an Era of Sustainable Development, New York City, New York (November 10-11, 2015); Columbia Center on Sustainable Investment, $13^{\text {th }}$ Annual Columbia International Investment Conference: Rethinking International Investment Governance: Principles for the 21 ${ }^{\text {st }}$ Century New York City, New York (September 27-28, 2018). Literature on barriers to FDI is rich. Core texts include John H. Dunning, Explaining International Production (1988); Foreign Direct Investment and Governments: Catalysts for Economic Restructuring (John H. Dunning and Rajneesh Narula, eds., 1997). See also UNCTAD, World Investment Report 2018: Investment and New Industrial Policies (2018), 16 (predicting that tax reforms in the U.S. would encourage repatriation of funds held overseas by U.S. MNEs and result in decreased inward FDI flows into other countries).

11 With respect to the latter example, investment incentives may be offered in an attempt to compensate for actual or perceived weaknesses as investment destinations. See generally, Rethinking Investment Incentives: Trends and Policy Options (Ana Teresa Tavares Lehmann, Perrine Toledano, Lise Johnson \& Lisa Sachs eds., 2016). OECD, Dispute Settlement Provisions in International Investment Agreements: A Large Sample Survey (OECD 2012 ), 8. See generally discussions in The Effect of Treaties on Foreign Direct Investment, supra note iii.

See, e.g., Pohl, supra note iii, at 36, n. 123. (2014); The Effect of Treaties on Foreign Direct Investment, supra note iii.. In contrast to studies on the effects of IIAs on investment flows, studies have shown that bilateral and regional trade agreements do have a positive impact on FDI. Max Büge, Do Preferential Trade Agreements Increase Their Members' Foreign Direct Investment? (German Development Institute/ Deutsches Institut für Entwicklungspolitik Discussion Paper 37/2014, 2014). 
See Kathryn Gordon, Joachim Pohl and Marie Bouchard, Investment Treaty Law, Sustainable Development and Responsible Business Conduct: A Fact Finding Survey (OECD Working Papers on International Investment, 2014/01, OECD Publishing, 2014). Agreement between Japan and the United Mexican States for the Strengthening of the Economic Partnership, signed September 17, 2009, art. 147(1).

See, Partnership Agreement between the Members of the African, Caribbean and Pacific Group of States of the One Part, and the European Community and Its Member States, of the Other Part, signed June 23, 2000, amended in 2005 and 2010, ch. 7.

See, e.g., José Henrique Vieira Martins, Brazil's Cooperation and Facilitation Investment Agreements (CFIA) and Recent Developments, Investment Treaty News (June 12, 2017); Lise Johnson, et al., International Investment Agreements, 2014: A Review of Trends and New Approaches, in Yearbook on International Investment Law and Policy 2014-2015, 15, $22-24$ (Andrea Bjorklund ed., 2016). Brazil Model Cooperation and Facilitation Investment Agreement, art. 18. Ibid.

See, e.g., David Gaukrodger, Investment Treaties and Shareholder Claims for Reflective Loss: Insights from Advanced Systems of Corporate Law (OECD Working Papers on International Investment 2014/02, 2014) (discussing relative treatment of shareholders); Lise Johnson, Lisa Sachs \& Jeffrey Sachs, Investor-State Dispute Settlement, Public Interest and U.S. Domestic Law (Columbia Center on Sustainable Investment Policy Paper, May 2015) (highlighting various ways in which protections under U.S. law differ from those under investment law); Lise Johnson, A Fundamental Shift in Power: Permitting International Investors to Convert their Economic Expectations Into Rights, 65 UCLA L. Rev. Disc. 106 (2018) (comparing the doctrine of estoppel under domestic law with that under investment law). Additionally, the treaties may offer other benefits such as market access rights, and stronger intellectual property protections. Furthermore, when investors sue states through ISDS, they are able to do so free from the restrictions on suit that may be relevant at the domestic level. These restrictions may relate to, for instance, limits on standing, ripeness, justiciability, and standards or availability of review. Johnson, Sachs \& Sachs, supra note xxii.

See, e.g., Committee on Economic, Social and Cultural Rights, General Comment No. 24 (2017) on State obligations under the International Covenant on Economic, Social and Cultural Rights in the context of business activities (calling for similar assessments of human rights impacts by home states in certain contexts).

24 See, e.g., the World Bank's Multilateral Investment Guarantee Agency's (MIGA) operational regulations provide that "legally prohibited activities such as narcotics production shall not be covered. MIGA shall not cover investments that do not comply with the national laws of the Host Country, including those that protect core labor standards." Multilateral Investment Guarantee Agency, Operational Regulations (As amended by the Board of Directors through August 27, 2002), available at: https://www.miga.org/sites/default/files/archive/Documents/miga documents/Operations-Regulations-030115.pdf, p. 31.

The United States Overseas Private Investment Corporation (OPIC), for instance, will not support "[c]onstruction of dams that significantly and irreversibly: (a) disrupt natural ecosystems upstream or downstream of the dam; or (b) alter natural hydrology; or (c) inundate large land areas; or (d) impact biodiversity; or (e) displace large numbers of inhabitants (5,000 persons or more); or (f) impact local inhabitants' ability to earn a livelihood." Overseas Private Investment Corporation, Environmental and Social Policy Statement, appendix B, 9 (January 2017).

26 OPIC also includes on its list of Categorically Prohibited Projects those projects for "[c]onversion or degradation of ... forestrelated Critical Natural Habitats." Id. 91.

27 The United States' OPIC's list of Categorically Prohibited Projects includes investments by "[c]ompanies which are treated as inverted corporations under 6 USC 395(b)." Overseas Private Investment Corporation, supra note xxv. OPIC, for example, implicitly recognizes the potential for negative consequences of outward-investment-promotion activities in pledging to "assesses the projected U.S. economic impact [of a given potential OPIC-supported project] to ensure it will not harm U.S. jobs or the U.S. economy" and "decline the support for any project that would result in the loss of U.S. jobs." OPIC, Our Investment Policies: U.S. Effect, https://www.opic.gov/who-we-are/OPIC-policies/US-effects.

29 See Committee on Economic, Social and Cultural Rights, supra note xxiii. See also Columbia Center on Sustainable Investment, Raising the Bar: Home Country Efforts to Regulate Foreign Investment for Sustainable Development 5-10 (Background Note to Ninth Annual Investment Conference, 2014) (noting legal and reputational arguments in favor of home state efforts to assess effects of investments they actively support).

30 Such references to the roles of home states under human rights law can be found, for instance, in the Committee on Economic, Social and Cultural Rights, supra note xxiii. See also, e.g., The Danish Institute for Human Rights and International Corporate Accountability Roundtable, National Action Plans on Business and Human Rights: A Toolkitfor the Development, Implementation, and Review of State Commitments to Business and Human Rights Frameworks, (June 2014). Analogous efforts to identify and avoid or mitigate harms from FDI are also taking place in the context of initiatives for screening inward FDI. One example of 
a screening framework is the Regulation of the European Parliament and of the Council Establishing a Framework for the Screening of Foreign Direct Investment into the Union, which came into force in April 2019. Social-Responsibility/Environment/Documents/enviro-policy.pdf.

Global Affairs Canada, Responsible Business ConductAbroad, (Nov. 26, 2018) http://www.international.gc.ca/trade-agreementsaccords-commerciaux/topics-domaines/other-autre/csr-rse.aspx?lang=eng.

See, e.g., OPIC, supra note xxv; Kernaghan Webb, Political Risk Insurance, CSR and the Mining Sector, 54 Int'l J. L. \& Mgmt. 394 (2012). In a highly visible case, OPIC cancelled the insurance policy of Freeport McMoRan's Grassberg mine in Papua after an environmental report revealed extensive environmental violations. Jane Perlez \& Raymond Bonner, Below a Mountain of Wealth, a River of Waste, N.Y. Times, December 27, 2005, https://www.nytimes.com/2005/12/27/world/asia/below-a-mountainof-wealth-a-river-of-waste.html. The German Investment Corporation offers another example of a government-owned entity using development criteria to inform, monitor and evaluate the projects it supports and try to advance positive outcomes. DEG, Our Impact: We Measure Development Outcomes, https://www.deginvest.de/International-financing/DEG/\%C3\%9Cber-uns/ Was-wir-bewirken/Wir-messen-Wirksamkeit/.

See, Overseas Private Investment Corporation, Annual Policy Report 2011, Exhibit 5: OPIC's Development Matrix Explained (2011).

See Colombia Model BIT, discussed in Jesse Coleman, et al., International Investment Agreements, 2017: A Review of Trends and New Approaches, in Yearbook on Int'l Inv. L. \& Policy 99, 128 (Lisa Sachs, Jesse Coleman, \& Lise Johnson, eds., 2018).

As noted above, some treaties condition protection on an investment being made in compliance with the law of the host state. See discussions in Rahim Moloo \& Alex Khachaturian, The Compliance with the Law Requirement in International Investment Law, 34 Fordham Int'l L.J. 1473 (2011). It is less common, however, to see requirements that such investments be maintained in accordance with the relevant laws. When investments are required to be maintained in accordance with domestic laws, questions will likely arise regarding, for instance, how to establish breach (e.g., is a conviction required?), and whether there will be any materiality requirement relating to the nature of the breach (e.g., intentional or negligent) or the nature of the law (e.g., relating to civil or criminal offenses) that will affect whether violation warrants exclusion from protection or ISDS. The authors are unaware of any treaty requiring that investors comply with the law of the home state in order to be protected by the home state's treaties, apart from requirements that the investor be a national of or incorporated in that state. See, e.g., Stephan Schill, Fair and Equitable Treatment, the Rule of Law, and Comparative Public Law, in International Investment Law and Comparative Public Law (Stephan Schill ed., 2010). Bonnitcha, supra note $\mathrm{xv}$, at 136-39.

40 See Pohl, supra note iii, at 55-69.

See, e.g., Sattorova, supra note vii; Bonnitcha, supra note xv, at 136 (discussing studies); see also, Gulnaz Sharafutdinova \& Karen Dawisha, The Escape from Institution-Building in a Globalized World: Lessons from Russia, 15 Persp. on Pol. 361 (2017) (discussing international arbitration, not limited to treaty-based arbitration). Bernard Robertson, Exhaustion of Local Remedies in International Human Rights Litigation: The Burden of Proof Reconsidered, 39 ICLQ 191(1990) 196.

43 Sachs \& Johnson, supra note vi, at 2.

44 See, e.g., Bear Creek Mining Corporation v. Republic of Peru, ICSID Case No. ARB/14/21, Award, November 30, 2017; Copper Mesa Mining Corporation v. Republic of Ecuador, PCA No. 2012-2, Award, March 15, 2016. Insulating the arbitrators in this manner from input by non-parties may also increase the likelihood that ISDS tribunals' decisions reflect economic and legal worldviews commonly shared by arbitrators, such as belief in the soundness of the policy prescriptions pronounced by the Washington Consensus. See, e.g., David Chriki, Is the Washington Consensus Really Dead? An Empirical Analysis of FET Claims in Investment Arbitration, 41 Suffolk Transnat'l L.Rev. 292, 304-06 (2018).

See, e.g., Enhanced Partnership and Cooperation Agreement between the European Union and its Member States, of the one part, and the Republic of Kazakhstan, of the other part, signed December 21,2015, art. 30, requiring each party to "ensure that its procedures for the development of technical regulations and conformity assessment procedures allow for public consultation of interested parties at an early appropriate stage when comments resulting from the public consultation can still be introduced and taken into account."; Agreement between Canada and Mongolia for the Promotion and Protection of Investments, signed September 8, 2016, art. 12. directing parties, to the extent possible, to publish regulatory proposals and provide interested persons and the other Party a reasonable opportunity to comment on such proposed measures."; 2012 U.S. Model Bilateral Investment Treaty, art. 11(2)-(3). It should be pointed out that a couple of factors soften requirements regarding advance publication of proposed rules and obligations to respond to comments. For one, several treaties only oblige governments to 
publish information "to the extent possible." Additionally, violations of these articles generally cannot be directly raised by investors in investor-state arbitration (though they may support allegations that a country has breached another article such as the article on fair and equitable treatment. See also UNCTAD, Series on Issues in International Investment Agreements II: Transparency (2012), 16-30.

See UNCTAD, Investor-State Dispute Settlement: Review of Developments in 2017, in 2 Int'l Inv. Agreements Issues Notes 1, 2 (2018), available at https://unctad.org/en/PublicationsLibrary/ diaepcbinf2018d2 en.pdf [https://perma.cc/NTE2-N67V], 5255. Cases interpreting the FET obligation to include such requirements of advance notice and/or an opportunity to respond are controversial, however, and have been subjected to critique and successful legal challenges. Metalclad v. Mexico, ICSID Case No. ARB(AF)/97/1, Award, August 30, 2000 (finding a breach of the FET obligation based, in part, on a lack of transparency); The United Mexican States v. Metalclad Corporation, Supreme Court of British Columbia, May 2, 2001 (accepting a challenge to the tribunal's reasoning and holding on transparency being an element of the FET standard). Investors can invoke the threat of an ISDS case, either subtly or directly, in private conversations with policy makers or through other non-public means, making it difficult to capture both specific instances of and the scale of such regulatory chill. Certain examples are known if, for instance, communications are leaked, a notice of claim is filed and subsequently revoked when the government reverses its policy, or a policy maker attests to the impact of such a threat. See, e.g., Mavluda Sattorova, Investor Responsibilities from a Host State Perspective: Qualitative Data and Proposals for Treaty Reform, 113 AJIL Unbound 22 (2019); Rochelle Dreyfuss \& Susy Frankel, Reconceptualizing ISDS: When is IP an Investment and How Much Can States Regulate It?, (New York University School of Law, Public Law \& Legal Theory Research Paper Series, Working Paper No. 18-23, April 2018) 11-12; Public Eye, Glivec in Colombia: New Leaked Letter from Novartis Attests to Pressure at the Highest Level (February 5, 2018), https://www.publiceye.ch/en/news/detail/glivec-in-colombia-new-leaked-letter-from-novartis-attests-to-pressureat-highest-level; Brook Baker \& Katrina Geddes, The Incredible Shrinking Victory: Eli Lilly v. Canada, Success, Judicial Reversal, and Continuing Threats from Pharmaceutical ISDS, 49 Loyola U. Chi. L. J. 479 (2017); Krzysztof J. Pelc, What explains the Low Success Rate of Investor-State Disputes, 71 International Organization 557 (2017); Harten \& Scott, supra note viii. For discussions of regulatory chill, including the different forms it may take, and the methods and challenges for documenting it, see Pohl, supra note iii, at 55-66; Kyla Tienhaara, Regulatory Chill and the Threat of Arbitration: A View from Political Science, in Evolution in Investment Treaty Law and Arbitration (Chester Brown and Kate Miles, eds., 2011).

Deserai A. Crow, Elizabeth A. Albright and Elizabeth Koebele, Environmental Rulemaking Across States: Process, Procedural Access, and Regulatory Influence, 34 Envtl \& Planning C: Pol. and Space 1222 (2016) (based on research on regulatory practices in several US states, finding support for their hypotheses that "technical expertise, procedural access, and relationships with regulators give some stakeholders (particularly industry) greater access and influence over rulemaking" id. at 1236); William F. West and Connor Raso, Who Shapes the Rulemaking Agenda? Implications for Bureaucratic Responsiveness and Bureaucratic Control, 23 J. Pub. Admin. Res. \& Theory 495, 498, 508-510 (2013) (finding that "the degree to which business and professional groups dominated other nongovernmental interests" in shaping the rulemaking agenda "is striking"); William F. West, Inside the Black Box: The Development of Proposed Rules and the Limits of Procedural Controls, 41 Admin. \& Soc'y 576 (2009) (raising concerns about informal, preliminary stages in rulemaking processes that precede formal statutory notice-and-comment procedures, and tensions with openness, inclusiveness, and democratic values that those early phases may generate); Nina A. Mendelson, Regulatory Beneficiaries and Informal Agency Policymaking, 92 Cornell L. Rev. 397 (2007).

50 See, e.g., Richard C. Chen, Bilateral Investment Treaties and Domestic Institutional Reform, 55 Colum. J. Trans. L. 547 (2017) (discussing some relevant options, including using BITs to strengthen the ability of domestic legal systems to effectively resolve investment disputes, and establishing ombudsmen-type systems to identify and address investment-related challenges). (Columbia Center on Sustainable Investment, February 21, 2018), http://ccsi.columbia.edu/2018/02/22/ what-do-we-mean-by-investment-facilitation/.

52 One frequent defense of ISDS is that it is necessary where local courts are unable to resolve the dispute, or when there is a bias in domestic courts and institutions. However, as of the time of writing the paper, of the more than 900 known ISDS cases, fewer than 10 allege lack of due process or bias in domestic courts. This is important because misplaced fear over the inability of domestic institutions to fairly resolve disputes further damages their legitimacy.

53 See, for instance, Oona A. Hathaway, Why Do Countries Commit to Human Rights Treaties, 51 J. Conflict Resolution 588 (2007) (discussing theories of why governments agree to and are more or less likely to commit to treaties limiting freedom to act). Lauge N. Skovgaard Poulsen \& Emma Aisbett, Relative Treatment of Aliens: Firm-level Evidence from Developing Countries 6 (Oxford Global Econ. Governance Programme, Working Paper No. 2016/122, 2016), available at https://www.geg.ox.ac. uk/publication/geg-wp-2016122-relative-treatment-aliens-firm-level-evidence-developing-countries [https://perma.cc/ 
P6QG-J3SG]. Indeed, investors' ISDS claims of nationality-based discrimination are relatively rare, and success on those claims even rarer. According to UNCTAD's data, as of January 21, 2019, there have only been nine successful claims based on the national treatment provision in investment treaties. The authors have analyzed those successful national treatment claims. None involved a clear finding by the tribunal that the investor had been discriminated against on account of its nationality. Clear examples of this are the relatively high-profile cases Philip Morris brought against Australia (Philip Morris Asia Ltd v. Australia, PCA Case No. 2012-12, Award on Jurisdiction and Admissibility, December 17, 2015) and Uruguay (Philip Morris Brands Sàrl v. Uruguay (ICSID Case No ARB/10/7, Award, July 8, 2016)). There was no suggestion that the challenged measures were adopted for anything other than a legitimate public purpose. Yet neither case was considered frivolous or easily dismissed. Andrew Sanger, Transnational Corporate Responsibility in Domestic Courts: Still Out of Reach?, 113 AJIL Unbound Symposium on Investor Responsibility: The Next Frontier in International Investment Law 4 (2019). John J. Parisi, Cooperation Among Competition Authorities in Merger Regulation, 43 Cornell Int'I L. J. 55 (2010) For some ideas of how to close governance gaps in IIAs to improve corporate accountability, see, e.g., Nathalie BernasconiOsterwalder \& Joe Zhang, Integrating Investor Obligations and Corporate Accountability Provisions in Trade and Investment Agreements: Meeting Report (April 2018), https://www.iisd.org/library/integrating-investor-obligations-and-corporateaccountability-provisions-trade. For discussion of possibilities for increased bilateral or multilateral efforts to address antitrust issues, see, e.g., UNCTAD, Corporate Rent-Seeking, Market Power and Inequality: Time for a Multilateral Trust Buster?, Policy Brief No. 66 (May 2018), 4.

59 Alessandra Mistura, Integrating Civil Liability Principles into International Investment Law: A Solution to Environmental Damage Caused by Foreign Investors?, in Yearbook on International Investment Law and Policy (Lisa Sachs, Jesse Coleman, \& Lise Johnson, eds., 2019).

As noted by the OECD, complying with the BEPS framework requires significant capacity and resources and can be challenging for developing countries to implement. See Inclusive Framework On BEPS: Progress Report July 2016-June 2017, pp 9. (OECD, 2017).

61 Mistura, supra note lix.

62 This point has been made in conversations the authors have had with individuals involved in conducting sustainability impact assessments. See also, e.g., Claire Gammage, A Sustainability Impact Assessment of the Economic Partnership Agreements: Challenging the Participatory Process, 3(1) Law \& Dev. Rev. 108 (2010).

See, e.g., James Harrison, et al., Governing Labour Standards through Free Trade Agreements: Limits of the European Union's Trade and Sustainable Development Chapters, 57 JCMS 260 (2019); United States Government Accountability Office, "Free Trade Agreements: U.S. Partners Are Addressing Labor Commitments, but More Monitoring and Enforcement Are Needed," Report to Congressional Requesters, November 2014; United States Government Accountability Office, "Free Trade Agreements: Office of the U.S. Trade Representative Should Continue to Improve Its Monitoring of Environmental Commitments," Report to Congressional Requesters, November 2014; United States Government Accountability Office, "Free Trade Agreements: Office of the U.S. Trade Representative Should Continue to Improve Its Monitoring of Environmental Commitments," Report to the Chairman, Committee on Finance, U.S. Senate, July 2009. 


\section{Columbia Center on}

Sustainable Investment

The Columbia Center on Sustainable Investment is a leading applied

research center and forum dedicated

to the study, discussion and practice of sustainable international investment.

\section{ccsi.columbia.edu}

Jerome Greene Hall

435 West 116th Street

New York, NY 10027

Phone: +1 (212) 854-1830

Email: ccsi@law.columbia.edu

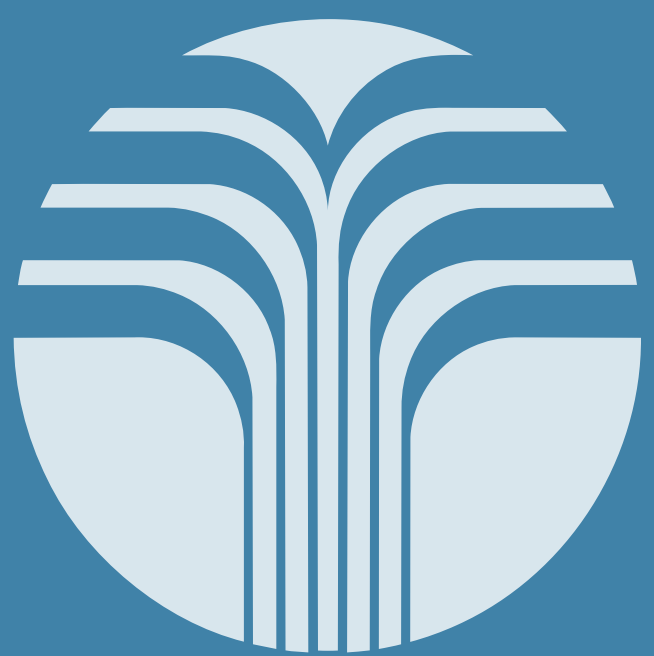

